\title{
Detection of protozoal Trichomonas vaginalis and abnormal vaginal flora in high vaginal smear
}

\section{Wills G. Sheela*, P. Vijayalakshmi, Mohanambal, Deepa Dharishini}

\begin{abstract}
Department of Obstetrics and Gynecology, Shri Sathya Sai Medical College and Research Institute, Ammapettai,
\end{abstract} Tamilnadu, India

Received: 25 July 2016

Accepted: 26 August 2016

*Correspondence:

Dr. Wills G. Sheela,

E-mail: drgwillssheelaa @yahoo.in

Copyright: ( $\odot$ the author(s), publisher and licensee Medip Academy. This is an open-access article distributed under the terms of the Creative Commons Attribution Non-Commercial License, which permits unrestricted non-commercial use, distribution, and reproduction in any medium, provided the original work is properly cited.

\begin{abstract}
Background: Vagina is the fibro muscular membrane sheath communicating with the uterine cavity and to the exterior at the vulva. Infection of female genital tract results from vaginal flora, extraneous agents and sexually transmitted diseases. The objective of the study was: a) high vaginal smear screening to find out incidence of abnormal vaginal flora of micro-organisms, b) prevalence of protozoal Trichomonas vaginalis.

Methods: Rural women from in and around Ammapettai in the age group of 20-50 years attending Gynaecology OPD of SSSMC\&RI for vaginal discharge and itching vulva. Exclusion criteria were age less than 20 and above 50 and pruritis vulva due to other causes the study size comprised of 50 women. After getting Institutional ethical committee's approval and written informed consent from the patients, detailed history regarding type of discharge, odour, itching, and associated bleeding was taken. Per speculum and per vaginal examination done. High vaginal smear for aerobic bacterial profile and Trichomonas infection were taken and transported to microbiology laboratory for staining and culture. Wet mount microscopic examination of Trichomonas vaginalis and Candidiasis with saline and $\mathrm{KOH}$ mount done.

Results: Out of 100 smears 9 were normal vaginal flora organisms, aerobic pathogens $43 \%$, Trichomonas vaginalis (TV) $30 \%$, and Candida albicans 5\% mixed infections on 7 smears. E. coli was seen in 23 samples, Klebsiella in 14, Pseudomonas aeroginosa 4, Staphylococcus in 6 samples. Gram negative organisms were $100 \%$ sensitive to imipenem, amikacin and gentamycin and $100 \%$ resistant to cefazolin, $80 \%$ to ceftazidime, $74 \%$ to cefotaxime. Gram positive staphylococcus $50 \%$ were resistant to gentamycin, ampicillin.

Conclusions: This study reflects on our responsibility to create awareness among women regarding abnormal vaginal discharge through proper health education routine screening targeted treatment to envisage healthy quality life.
\end{abstract}

Keywords: Aerobic microbes, E. coli, Staphylococcus aureus, TV

\section{INTRODUCTION}

Vagina is the fibro muscular membrane sheath communicating with the uterine cavity and to the exterior at the vulva. Infection of female genital tract results from vaginal flora, extraneous agents and sexually transmitted diseases. Vaginal flora has complex microbacteria in varying quantities and relative proportions maintaining intricate balance of gram negative aerobic and gram positive anaerobic microbes. Most important microbe that maintains vaginal flora is Lactobacilli. In the Lactobacillous dominant flora, various clinical effects are caused by variation of $\mathrm{pH}$, activation of polymicrobial agents and sexually transmitted protozoa, Trichomonas vaginalis. Smears deficient in Lactobacillus, positive for cocci with clue cells are diagnosed as bacterial vaginosis'. ${ }^{1}$ Deficient Lacto smears with positive for cocci, coarse bacilli, para epithelial cells and vaginal 
leucocytes are diagnosed as gram positive aerobic vaginalis. Aerobic gram negative microbes in vaginal flora are E.coli, Klebsiella pneumonia, Oxytocica, Pseudomonas aeroginosa, Staphylocoocus pyogenes, Staphylococcus aureus and epidermidis'. ${ }^{1}$

The study was conducted in sexually active rural women in reproductive age to find out the incidence of aerobic microbes and protozoal Trichomonas vaginalis and to formulate modalities for proper health education, screening and pre-targeted treatment.

\section{METHODS}

50 sexually active women living in and around Ammapettai village, Tamil Nadu, India in the age group of 20-50 years attending gynaecology OPD of Shri Sathya Sai Medical College and Research Institute, over a period of 6 months for vaginal discharge and itching in the vulva were recruited as study subjects. Age $<20$ years and $>50$ years, itching in the vulva due to other causes were excluded from the study. After getting institutional ethical committee's approval and informed written consent from the study subjects, detailed history regarding type of discharge, odour, itching and associated bleeding was taken. Per speculum and per vaginal examination was done. High vaginal smear for aerobic bacterial profile and trichomonas infection were taken and transported to microbiology laboratory for staining and culture.

High vaginal swab for aerobic pathogens was cultured into Macconkey blood, chocolate and Sabouraud's dextrose agar. Incubated at $37^{\circ} \mathrm{C}$ for 48 hours. Culture plates were examined for colony growth and processed upto species level identification and antibiotic sensitivity. Direct wet mount with saline and $\mathrm{KOH}$ was examined by microscopic examination. The culture was performed with Kupferberg media. The swab was inoculated into the media and incubated at $37^{\circ} \mathrm{C}$ for 7 days. The same was inoculated into Sabouraud's dextrose agar and fungal colonies grown were identified upto species level. Both wet mount, microscopic and Giemsa's staining was done for Trichomonas vaginalis.

\section{RESULTS}

Analysis of vaginal discharge in sexually active women from rural Ammapettai, Tamil Nadu, India, attending Gynaec OPD of SSS Medical college and Hospital lead to wide range of microbial profile including bacterial, parasitic, fungal agents.

Aerobic gram negative pathogens were the main study pathogens. 100 high vaginal smear from 50 women in the age group of 25-50 years were cultured for aerobic and anaerobic pathogens. Wet mount microscopy in $\mathrm{KOH}$ and saline for Candida and Trichomonas vaginalis, special stain giemsa and culture with Kupferberg media for Trichomonas infection was done.

\section{DISCUSSION}

Prevalence of aerobic pathogens is shown in Table 1. In present study of 9 smears showed normal vaginal flora 7 mixed infections, 30 Trichomonas vaginalis, 5 Candidiasis 43 were positive for aerobic and 6 for anaerobic pathogens. Gilbert GG Donders from Belgium has reported in his study $10 \%$ were aerobic pathogens. ${ }^{5}$ Sandhya R from Andhra Pradesh found aerobic microbes were $14 \%$ and Shameem Mumtaz from Abottabad, Pakistan has reported $21-30 \%$ of aerobic microbes and Karthika from silk city $54 \%$. $^{2-4}$

Table 1: Prevalence of aerobic pathogens.

\begin{tabular}{|l|l|}
\hline Normal vaginal flora & -9 \\
\hline Mixed infections & -7 \\
\hline Trichomonas vaginalis & 30 \\
\hline Candida & 5 \\
\hline Positive for aerobes & 43 \\
\hline Positive for anaerobes & 6 \\
\hline
\end{tabular}

Table 2: Age groups.

\begin{tabular}{|l|l|}
\hline Age group & 20 \\
\hline 20-25 years & 21 \\
\hline 26-30 years & 33 \\
\hline $31-35$ years & 15 \\
\hline 36-40 years & 07 \\
\hline $41-45$ years & 04 \\
\hline $46-50$ years & \\
\hline
\end{tabular}

Table 3: Age group correlation with.

\begin{tabular}{|l|l|l|}
\hline Years & No. of $T V$ & No. of Candidiasis \\
\hline $20-30$ & 21 & nil \\
\hline $31-40$ & 4 & 5 \\
\hline $41-50$ & 4 & nil \\
\hline 51 and above & nil & 2 \\
\hline Total & 30 & 7 \\
\hline
\end{tabular}

$T V$ more common in 20-30 years. TV infections was more common in young age group and candidiasis in the middle age group. These women present with severe pruritis vulva with DM.

Incidence of Trichomonas vaginalis was assessed by wet mount microscope, culture and giemsa stain. Many studies have been done showing varying incidences. In present study $30 \%$ women showed $T V$ +ve smear, Gilbert $10-30 \%$, Sandhya R 30-35\%, Shameem $45-50 \%$ in Pakistani women, Karthika-30\% in Indian women, Barry L Harnes 14-35\% in South Carolina women and Yasmeen $13.6 \%$ TV in Pakistani women. ${ }^{1-6}$ Prevalence of STD, protozoal, $T V$ infection was $30 \%$ average in women from various countries.

Candidiasis was studied in wet mount $\mathrm{KOH}$. In present study $7 \%$ women had vaginal candidiasis these were 
obese, diabetic, presented with curdy white discharge and bleeding PV Shameem from Pakistan had 6-10\% smear showing candidiasis. ${ }^{3}$ Karthika incidence was $2 \%$ and Bary L Harnes 17-39\% Candidiasis from South Carolina women. ${ }^{4,5}$ Yasmen from Pakistan has quoted TV incidence $13.6 \% .^{6}$ Distribution of aerobic and anaerobic pathogen shown in Table 4. Analysis of vaginal discharge in the present study, bacteria was positive in 49 women out of which $43 \%$ was aerogenic gram negative and $6 \%$ gram positive microbes. Normal vaginal flora $9 \%$, mixed infection in $7 \%$ were seen. Most common aerobic pathogen was E.coli and next was Klebsiella. In the present study E.coli was seen in 23 smears. Klebisella oxytocica in 8, Klebsiella pneumonia in 6< Pseudomonas aeruginosa in 4. Gram positive Staphylococcus aureus seen in 6 smears. Incidence of E.coli in Gilbert's study $35-40 \% .^{1}$ Sandhya $35-45 \%$, karthika $21 \%$, Shameem $54 \% .^{2-4}$ All these observation by various authors or similar as ours. Next common gram negative pathogen was Klebsiella in present study. $14 \%$ smears were positive for klebsiella in Gilbert study 7-8\% klebsiella and $6-8 \%$ were Staphlococcus aureus. ${ }^{1}$ Sandhya Staphylococcus aureus 4-6\% Klebsiella 13\%. ${ }^{2}$ Shameem Klebsiella was seen 9-10\% Staphylococcus aureus in 5\% smears Karthika Klebsiella in 36 smears and Staphylococcus aureus in $16 \% .^{3,4}$ In present study Staphylococcus aureus gram positive organism was seen in 3 smears Staphylococcus epidermidis 1 pyogenes 1 enterococcus $20 \%$. $23 \%$ smears were positive for E.coli pathogen.

Table 4: Distribution of micro-organisms.

\begin{tabular}{|l|l|l|l|l|l|}
\hline Gram positive aerobes & No & Gram negative aerobes & No & Miscellaneous & No \\
\hline Staphylococcus & & E.coli & 23 & Normal vaginal flora & 9 \\
\hline 1) aureus & 3 & Klebsiella oxytoca & 8 & Mixed infections & 7 \\
\hline 2) epidermidis & 1 & Klebsiella pneumoniae & 6 & TV positive & 30 \\
\hline 3)pyogenes & 1 & Pseudomonas aeroginosa & 4 & Candidiasis & 5 \\
\hline Enterococci & 1 & Acetinobacter bowmanii & 2 & & \\
\hline Total & 6 & & 43 & & \\
\hline
\end{tabular}

Prevalence of gram negative aerobes $43 \%$, Prevalence of gram positive anaerobes $6 \%$

Sensitivity pattern in aerobic and anaerobic microbes is shown in Table 5.

We had 43 smears positive for gram negative aerobes. Sensitivity pattern of aerobic pathogens showed $100 \%$ sensitivity to imipenem, amikacin and gentamycin. They were $100 \%$ resistant for cefazolin $80 \%$ ceftazidime and
$75 \%$ for cifoloxmine. Gram positive staphylococci were $100 \%$ sensitive to oxacillin $50 \%$ were resistant to gentamycin and ampicillin. Similar observations have been made by Sandhya R, Shameem, Karthika where E.coli was the predominant aerobic gram negative bacilli shown in vaginal smears and they were highly sensitive to amikacin and gentamycin. ${ }^{2-4}$

Table 5: Sensitivity pattern.

\begin{tabular}{|c|c|c|c|c|c|c|}
\hline \multirow{2}{*}{ Name of bacteria isolated } & \multicolumn{6}{|c|}{ Sensitivity pattern } \\
\hline & IMI\% & AK\% & G\% & $\mathrm{CZ} \%$ & CA \% & CE\% \\
\hline Escherichia coli & 100 & 100 & 100 & 0 & 20 & 26 \\
\hline Klebsiella oxytoca & 100 & 100 & 100 & 0 & 20 & 26 \\
\hline Klebsiella pneumoniae & 100 & 100 & 100 & 0 & 20 & 26 \\
\hline Pseudomonas aeroginosa & 100 & 100 & 94 & 0 & 15 & 22 \\
\hline Acinetobacter baumanii & 100 & 100 & 90 & 0 & 10 & 20 \\
\hline Staphylococcus epidermidis & - & 90 & 100 & 10 & 100 & 100 \\
\hline
\end{tabular}

IMI- imipenem AK- amikacin G- gentamycin CE- cefazolin CA-ceftazidime CE- cefotaxime. Staphlococcus epidermidis 100\% sensitive for oxacillin and vancomycin, resistant 50\% to gentamycin, ampicillin. Gram negative bacilli- resistant for cefazolin $100 \%$, ceftazidime $80 \%$ and cefotaxime $74 \%$.

\section{CONCLUSION}

The analysis shows the correlation between bacterial and parasitic infections common among sexually active women. Women with poor personal hygiene, malnutrition, anemia come with recurrent episodes of vaginitis. Unprotected coitus and unhygienic practices help in transmitting STD, HIV AND HSV infections. Recurrent vaginal infection is common in women because of close proximity of vaginal wall, urethra and anus. In the present study the incidence of abnormal vaginal flora was $43 \%$. STD protozoals Trichomonas 
vaginalis $30 \%$ anerobic vaginal anerobes were $6 \%$ Candidiasis $5 \% 23 \%$ of aerobic gram negative microbes was E.coli followed by Klebsiella $14 \%$. In gram-negative anaerobes were $100 \%$ sensitive to imipenem, amikacin and gentamycin. Staphylococcus were $50 \%$ resistant to amikacin and garamycin but $80 \%$ sensitive to ampicillin and amoxicillin. This study reflects on our responsibility to create awareness among women regarding abnormal vaginal discharge through proper health education routine screening targeted treatment to envisage healthy quality life.

Funding: No funding sources

Conflict of interest: None declared

Ethical approval: The study was approved by the Institutional Ethics Committee

\section{REFERENCES}

1. Donders GG, Vereecken A, Bosmans E, Dekeersmaecker A, Salembier G, Spitz B. Definition of a type of abnormal vaginal flora that is distinct from bacterial vaginitis. BJOG. 2002;109(1):34-43.

2. Sandhya R, Laxmipriya R, Esthermary. Prevalence of aerobic vaginal pathogens and antibiotic sensitivity pattern in tertiary care hospital. Res J Pharm Bio Chem Sci. 2014;5(6):936-40.

3. Mumtaz S, Ahmad M, Aftab I, Akhtar N, Hassan M, Hamid A. Aerobic pathogens and their sensitivity pattern. J Ayub Med Coll Abbottabad. 2008;20(1):113-7.

4. Jayakumar K, Keerthana, Divya G, Sivakami, Jayalakshmi S. The aerobic bacterial profile of high vaginal swab in suburban Chennai. JBPAS. 2015;4(4):2042-46.

5. Harner BL, Gibson MV. Vaginitis: Diagnosis and treatment. Medical University of South Carolina, Charleston, South Carolina. Am Fam Physician. 2011;83(7):807-15.

6. Houso Y, Farraj MA, Ramlawi A, Essawi T. Detection of Trichomonas Vaginalis in vaginal swab clinical samples from Palestine women by culture. ISRN Microbiol. 2011;2011:872358.

Cite this article as: Sheela WG, Vijayalakshmi P, Mohanambal, Dharishini D. Detection of protozoal Trichomonas vaginalis and abnormal vaginal flora in high vaginal smear. Int J Reprod Contracept Obstet Gynecol. 2017;6:563-6. 